\title{
Local anaesthetics in postoperative pain relief - what is their role?
}

Neal H. Badner MD FRCPC

The role of local anaesthetics for postoperative analgesia will be approached by answering the following questions:

1 What blocks are effective?

2 When should the injection occur?

3 What local anaesthetic should be used?

\section{Potential blocks}

Starting centrally from the neuraxis, pain transmission can be blocked using local anaesthetics with injections at the following sites: subarachnoid space (spinal), epidural space, nerve plexuses (brachial, lumbar), major nerves (intercostal, interpleural), and peripheral receptors (wound infiltration, intraarticular injection).

\section{Spinal}

Local anaesthetics have been injected into both the intrathecal and epidural spaces for surgical anaesthesia since the early 1900s. Although the duration of anaesthesia with the longer-acting agents, tetracaine or bupivacaine is no more than three to four hours, for some procedures such as endoscopic urological surgery, single injections of $5 \%$ lidocaine $\left(0.5 \mathrm{mg} \cdot \mathrm{kg}^{-1}\right)$ can produce analgesia for an average of $11 \mathrm{hr}^{1}{ }^{1}$ For more major procedures, however, the duration of analgesia is more limited.

The duration of spinal local anaesthetic analgesia can be extended with the use of indwelling catheters. Until recently they have not been used in the postoperative period for fear of postdural puncture headache and/or infection. With the introduction of $26-32$ gauge (G) microcatheters, and the subsequent low incidence of headache, continuous spinal anaesthesia has now been used for postoperative analgesia. In one study of ten patients undergoing vascular procedures, lidocaine, in concentrations of $0.5-2.0 \%$, was infused at $2-10 \mathrm{ml} \cdot \mathrm{hr}^{-1}$ for up to $48 \mathrm{hr}^{2}$ This provided "excellent" analgesia, and only two patients required supplemental morphine. In this study half the patients had $28 \mathrm{G}$ catheters and half had $18 \mathrm{G}$ catheters. There was no evidence of haemodynamic instability or motor block, however $2 / 5$ patients in whom a $28 \mathrm{G}$ catheter was used experienced pump occlusion difficulty. A follow-up study showed no increased risk of infection in 19 similar patients. ${ }^{3}$ In another study the addition of morphine was found to improve analgesia further and allow lower lidocaine concentrations of $0.1-0.2 \%{ }^{4}$ However, subsequent to these studies, two case reports were published describing the development of cauda equina syndrome in six patients in whom microcatheters had been used intraoperatively. The presumed aetiology was maldistribution of large amounts of $5 \%$ hyperbaric lidocaine which can be neurotoxic. These reports lead to the withdrawal of these microcatheters from use by the FDA. Attempts are being made to reintroduce modified microcatheters which will avoid this problem. If the attempts are successful, further studies will be needed to determine the long-term safety of this technique, or whether the use of larger $18 \mathrm{G}$ catheters is acceptable.

\section{Epidural}

As with spinal anaesthesia, single-shot epidural anaesthesia has a limited duration of action and is therefore not often used for postoperative analgesia. This technique is commonly used in paediatric ambulatory patients using the caudal approach to the epidural space. Bupivacaine $0.25 \%$ in doses of $0.5-1.0 \mathrm{ml} \cdot \mathrm{kg}^{-1}$ provides analgesia for four to six hours following herniorrhaphy, orchidopexy, and hypospadias repair. Side effects include difficulty with ambulation and delayed micturition, but hospital discharge is not delayed. ${ }^{5}$

Unlike spinal use, larger $20 \mathrm{G}$ ind welling catheters have been used in the epidural space for many years with minimal complications. This has allowed repeated dosing and is the most common form of postoperative use. The use of epidural local anaesthesia for postoperative pain management has been reported following abdominal, thoracic, and orthopaedic surgery.

The local anaesthetic most commonly used is bupivacaine due to its ability to block sensory fibres preferentially. When deposited into the epidural space it diffuses rapidly through the dura and CSF to the spinal cord

From the Department of Anaesthesia, University Hospital, University of Western Ontario 
where blockade of neuronal transmission is the presumed site of action. The degree of blockade depends on the concentration and volume of local anaesthetic used. Intermittent doses of $5-10 \mathrm{ml}$ of bupivacaine $0.5 \%$ given through thoracic level epidural catheters have provided good analgesia following either thoracotomy or upper abdominal surgery, while 8-12 $\mathrm{ml}$ given through lumbar catheters have also been effective following lower abdominal surgery. The duration of analgesia is, however, only three to four hours, so one can use continuous infusions of lower concentrations, e.g., $3-10 \mathrm{ml} \cdot \mathrm{hr}^{-1}$ of $0.25 \%$ or $5-15 \mathrm{ml} \cdot \mathrm{hr}^{-1}$ of bupivacaine $0.125 \%$. This produces good analgesia following thoracotomy, upper abdominal surgery, and knee joint replacements.

Possible beneficial effects on pulmonary and endocrine function have not been demonstrated consistently. Following upper abdominal surgery epidural anaesthesia did not improve patients' oxygenation or expiratory flow compared with systemic morphine, ${ }^{6}$ but there was a decreased "convalescent time." Buckley et al. showed a decreased incidence of pulmonary complications in morbidly obese patients undergoing abdominal surgery with epidural analgesia. ${ }^{7}$ Effects on the metabolic stress response to surgery, i.e., the ability to block the rise in cortisol, insulin and glucagon, seem to depend on the location of surgery. Patients who have undergone lower abdominal surgery have not had this hormonal rise, whereas those who have undergone upper abdominal surgery have, in spite of a high thoracic block postoperatively. 8,9

The major problem with the use of epidural local anaesthetics is the side effects. The side effects relate to the mechanism of action, sympathetic block causing hypotension, or motor block causing muscle weakness. When used following thoracotomy or upper abdominal surgery, the majority of patients in one study developed hypotension requiring treatment, ${ }^{6}$ and in another following knee joint replacement, over half of the patients had some motor block for the first $48 \mathrm{hr} .{ }^{10}$ As well as being troublesome to patients, both of these side effects limit the ability to ambulate, which is one of the goals of good postoperative analgesia. For these reasons, though effective, the use of epidural local anaesthetics alone has not become popular for postoperative analgesia.

Recently, attempts to decrease the dose of the more commonly used epidural opioids has led to the use of epidural infusions of a mixture of narcotic and local anaesthetic. Theoretically, as the two drugs act by different mechanisms their effects should be synergistic and this should allow decreased amounts of each drug, and thereby minimize the incidence of side effects of local anaesthetics and the nausea and vomiting, pruritus, urinary retention and respiratory depression after epidural opioids. Epidural morphine combined with 0.5 bupiva- caine as an infusion totally relieved pain after upper abdominal surgery. "The patients all had a high thoracic sensory block, and $20 \%$ required treatment for hypotension. Conversely, the combination of $0.1 \%$ bupivacaine with either epidural fentanyl or morphine did not produce added analgesia following either thoracotomy and upper abdominal surgery, ${ }^{12,13}$ or knee joint replacement. ${ }^{14}$ Concentrations of bupivacaine between 0.1 and $0.5 \%$ seem to be needed. This has been confirmed in several recent studies where the addition of $0.125 \%$ and $0.25 \%$ bupivacaine has been shown to be superior to epidural morphine or fentanyl alone with $0.125 \%$ bupivacaine having the least number of side effects. ${ }^{15,16}$ Most importantly, combinations of epidural opioid and local anaesthetic have decreased morbidity and mortality when compared with systemic narcotics in high risk surgical patients, possibly through effects on the coagulation system. ${ }^{17,18}$

\section{Nerve plexuses}

BRACHIAL

As with single injections in the spinal and epidural spaces brachial plexus block also produces postoperative analgesia of limited duration. Like the spinal and epidural spaces, catheters can be placed near the brachial plexus via the axillary, and interscalene approaches. Infusions of $3-10 \mathrm{ml} \cdot \mathrm{hr}^{-1}$ of bupivacaine $0.125-0.25 \%$ have produced good analgesia and decreased opioid requirements following various upper limb procedures. ${ }^{19,20}$ The use of bupivacaine $0.125 \%$ is recommended as $0.25 \%$ resulted in symptoms of toxicity in $3 / 20$ patients in one study. ${ }^{21}$ Catheter placement in these locations is technically much more difficult, and they are more prone to dislodge with movement. The major complication is systemic toxicity from absorption of local anaesthetic. This risk increases with increasing local anaesthetic concentration as noted above, and with increasing duration of infusion.

\section{LUMBAR}

Similar to the brachial plexus, injections of the lumbar plexus either in the psoas compartment or by using the femoral "3 in 1" approach can produce analgesia following lower limb procedures. Twenty-thirty $\mathrm{ml}$ of bupivacaine $0.5 \%$ can reduce opioid requirements following anterior cruciate ligament repair for $24 \mathrm{hr}$. Catheters can also be inserted into both locations and have been used following hip and knee surgery. Following knee surgery, infusions of $5-10 \mathrm{ml} \cdot \mathrm{hr}^{-1}$ of bupivacaine $0.25 \%$ into femoral sheath catheters have been shown to be superior both to placebo, ${ }^{22}$ and the intraarticular injection of morphine or bupivacaine (see below), ${ }^{23}$ while producing equal analgesia and lower incidences of side effects (nausea, vomiting, pruritus, and urinary retention) than epidural 
morphine. ${ }^{24}$ These amounts of bupivacaine can lead to high systemic concentrations, and hence similar infusions of $0.125 \%$ are recommended. Equivalent infusions of bupivacaine into the psoas compartment have also reduced PCA narcotic requirements following hip surgery. ${ }^{25}$ As with continuous brachial plexus blocks these procedures are technically more difficult to perform than epidural or spinal catheter insertion.

\section{Major nerves}

\section{INTERCOSTAL BLOCKS}

These blocks are performed by the injection of $3 \mathrm{ml}$, local anaesthetic, usually bupivacaine $0.5 \%$, just inferior to the appropriate rib, $7-8 \mathrm{~cm}$ from the posterior midline. They can provide analgesia and improve pulmonary function following thoracic surgery (injecting the two ribs above and below the incision) or upper abdominal surgery (ribs \#7-11) equal to that from epidural morphine. ${ }^{26}$ The duration of action is in the four- to sixhour range, at which time five more injections must be made. This is both labour intensive and painful, and can be avoided by having the surgeon insert one or two catheters subpleurally into an intercostal space when performing thoracic surgery. Postoperatively, injection of $20 \mathrm{ml}$ bupivacaine $0.5 \%$ with $1: 200,000$ epinephrine into the catheter provides improved analgesia, decreased opioid requirements, and improved pulmonary function ( $F E V_{1}$, FVC, PEFR) compared with placebo, ${ }^{27}$ and may provide equal analgesia with fewer side effects when compared with epidural morphine. ${ }^{28}$ This technique however, obviously requires interest and assistance from the surgeon.

\section{INTERPLEURAL BLOCKS}

This technique was first reported in the mid 1980s. The procedure involves the insertion of a Touhy needle attached to an air-filled syringe into the eighth or ninth intercostal space, approximately $10 \mathrm{~cm}$ from the midline. The interpleural space is identified when its negative pressure causes the plunger of the syringe to descend. This is followed by insertion of a catheter through the needle. Injection of local anaesthetic presumably produces analgesia by diffusion into the paravertebral space where it can disperse blocking multiple intercostal nerves. After open cholecystectomy, injection of $20 \mathrm{ml}$ of bupivacaine $0.5 \%$ with 1:200,000 epinephrine produces good analgesia that lasts on average for six hours and leads to improved $\mathrm{FEV}_{1}$, and FVC compared with systemic opioids. ${ }^{29}$ These factors combined with the relative simplicity of the procedure compared with intercostal blocks led to its early popularity in spite of the increased risk of pneumothorax, shorter duration of action and higher systemic absorption of bupivacaine. ${ }^{30}$ When used following thoracotomy, however, randomized studies have shown no added benefit compared with placebo, and clear inferiority to epidural morphine. ${ }^{31}$ The switch to laparoscopic cholecystectomy will likely minimize the use of this technique in the future.

\section{Peripheral receptors}

\section{WOUND INFILTRATION}

The simple injection of local anaesthetic into the wound can produce analgesia that outlasts the local anaesthetic. The injection of $40 \mathrm{ml}$, bupivacaine $0.25 \%$ to patients undergoing inguinal herniorrhaphy has created superior analgesia for $48 \mathrm{hr}$ when compared to uninjected patients. ${ }^{32}$ The local anaesthetic does not even have to be injected, as $200 \mathrm{mg}$ lidocaine aerosol sprayed over similar inguinal herniorrhaphy patients' wounds also produced decreased opioid requirements and increased analgesia for $24 \mathrm{hr}$ compared with placebo. In this study there was no evidence of wound infection and systemic absorption was minimal. ${ }^{33}$ Wound infiltration is also effective following tonsillectomy, where injection of 3-5 ml bupivacaine $0.25 \%$ with $1: 200,000$ adrenaline can produce improved analgesia for five days. ${ }^{34}$ However, this technique is not effective for more major surgery, involving viscera such as abdominal hysterectomy. ${ }^{35}$

\section{INTRAARTICULAR}

The relatively simple procedure of injecting local anaesthetics, usually bupivacaine, into a joint following arthroscopic surgery can also decrease opioid requirements and the time to ambulation compared with placebo. ${ }^{36}$ Volumes of $20-30 \mathrm{ml}$, bupivacaine $0.25 \%-0.5 \%$ injected prior to tourniquet release are used. These amounts are based on the findings that injecting $40 \mathrm{ml}$ bupivacaine $0.25 \%$ (100 mg) following knee arthroscopy has led to minimal systemic absorption. ${ }^{37}$ yet injecting $30 \mathrm{ml} \mathrm{bu-}$ pivacaine $0.75 \%$ (225 $\mathrm{mg}$ ) has produced toxic concentrations in $4 / 15$ patients. ${ }^{38}$ Recent discovery of the existence of peripheral narcotic receptors has led to the use of intraarticular morphine (1-5 mg) combined with bupivacaine. This combination seems to offer superior analgesia to either drug alone. ${ }^{39}$ The majority of studies to date have involved knee surgery although the use of intraarticular morphine and bupivacaine has been reported to provide effective analgesia following frozen shoulder manipulation.

\section{Timing}

Intuitively, it would appear that the optimal timing of injection would be at the end of the procedure, thus producing the longest-lasting analgesia. However, animal studies have shown that blockade prior to creation of 
the wound may be superior. The basis for this theory is that, following an initial noxious stimulus, input from the sensory neurons to the dorsal horn results in dorsal horn interneuron output greater than the initial stimulus. These interneurons, as well as synapsing with ascending neurons. also synapse with efferent neurons to the injured tissue, which then feeds back to the dorsal horn again. This creates a loop that positively feeds back on itself, creating a "windup" phenomenon whereby the response exceeds the initial stimulus. ${ }^{40}$ Blocking the initial afferent transmission prior to injury ("preemptive blockade") could prevent this windup from occurring. The result, therefore, would be better analgesia than a block instituted after the injury when the windup is already occurring.

Attempts to verify this clinically in humans have met with mixed results. Spinal anaesthesia, which is a form of preemptive blockade, compared with general anaesthesia, does lead to lower pain perception for up to 48 $\mathrm{hr}$ following inguinal herniorrhaphy. ${ }^{32}$ However, patients undergoing general anaesthesia combined with a preincisional epidural block have not had decreased opioid requirements or improved analgesia following either abdominal hysterectomy or colonic surgery than with similar postincisional or post wound closure epidural supplementation. ${ }^{41,42}$ Similarly, intercostal nerve blocks prior to incision were no more effective than placebo in producing postoperative analgesia in thoracotomy patients undergoing general anaesthesia. ${ }^{43}$ Lastly, lumbar plexus blocks using the femoral nerve " 3 in 1 " technique were also no more efficacious when given prior to total hip replacement as compared with after, though both were more effective than no block in decreasing postoperative opioid requirements. ${ }^{44}$ Wound infiltration with local anaesthetics during inguinal hernia repair has shown evidence of preemptive analgesia, and preincisional injection yielded superior analgesia when compared with similar postincisional injections. ${ }^{45}$ However, a similar study comparing preincisional with postincisional wound infiltration showed no difference in postoperative wound pain. ${ }^{46}$ Clearly, more investigation is needed at this time to determine what blocks, if any, are more appropriate to administer prior to the incision.

\section{Local anaesthetics}

As noted, the most commonly used local anaesthetic is bupivacaine. Aside from specific procedure-related side effects, systemic toxicity is the most serious complication. For local anaesthetics, this means neurological and cardiac toxicity, in the form of excitability and/or depression. Neurologically, this manifests as seizures, and/or loss of consciousness, while cardiac toxicity results in arrhythmias or cardiac arrest. Bupivacaine has been recognized to be inherently more cardiotoxic than other local anaesthetics such as lidocaine, and this cardiotoxicity may be enhanced during pregnancy.

This has led to the development of ropivacaine, an analogue of bupivacaine, which possesses a propyl side chain instead of a butyl side chain found on bupivacaine. They both have similar physical properties with ropivacaine being a little less lipid-soluble. The other difference is that bupivacaine is produced as a racemic mixture while ropivacaine is supplied as the $\mathrm{S}(-)$ enantiomer. The $\mathrm{S}(-)$ enantiomer has been shown to be less cardiotoxic and to possess a longer duration of action than the $R(+)$ or racemic mixture in animals. ${ }^{47}$ Ropivacaine's cardiotoxicity, compared with bupivacaine, is substantially less in animal models, ${ }^{48}$ and there is no change with pregnancy. ${ }^{49}$ In human volunteers, intravenous ropivacaine caused fewer neurological symptoms at similar dosages, while higher dosages and systemic concentrations were required to produce equal depression of cardiac conductivity and contractility. ${ }^{50}$ Clinically, use of ropivacaine $0.5 \%$ for both epidural and brachial plexus block has produced motor and sensory blockade similar in onset and equal in degree to bupivacaine $0.5 \%{ }^{51,52}$ but the duration of action was slightly shorter with ropivacaine. Currently, postoperative epidural studies using continuous infusions are in progress and should be reported shortly.

\section{References}

1 Patel D, Janardham Y, Merai B, Robalino J, Shevde K. Comparison of intrathecal meperidine and lidocaine in endoscopic urologic procedures. Can J Anaesth 1990; 77: 567-70.

2 Bevacqua BK, Slucky AV, Adusumilli SB. Post-operative analgesia with continuous intrathecal lidocaine infusion. Anesthesiology 1990; 73: A833.

3 Bevacqua B, Slucky $A$, Nemec $C$. Is postoperative intrathecal catheter use associated with CNS infections? Anesthesiology 1990; 73: A791.

4 Bevacqua BK, Slucky $A V$, Nemec D. Intrathecal lidocaine/morphine for postoperative pain ablation. Reg Anesth 1992; 17: 1S:6.

5 Fisher QA, McComiskey CM, Hill JL, et al. Postoperative voiding interval and duration of analgesia following peripheral or caudal nerve blocks in children. Anesth Analg 1993; 76: 173-7.

6 Pflug AE, Murphy TM, Butler SH, Tucker GT. The effects of postoperative peridual analgesia on pulmonary therapy and pulmonary complications. Anesthesiology 1974; 41: 8-17.

7 Buckley FP, Robinson NB, Simonowitz DA, Dellinger EP. Anaesthesia in the morbidly obese. Anaesthesia 1983; 38: 840-51.

8 Rem J, Moller IW, Brandt MR, Kehlet $H$. Influence of 
epidural analgesia on postoperative changes in various serum enzyme patterns and serum bilirubin. Acta Anaesthesiol Scand 1981; 25: 142-5.

9 Kossman B, Vokk E, Spilkes ED, et al. Influence of thoracic epidural analgesia on glucose, cortisol, insulin and glucagon responses to surgery. Reg Anesth 1982; 7: 107.

10 Raj PP, Knarr DC, Vigdorth E, et al. Comparison of continuous epidural infusion of a local anesthetic and administration of systemic narcotics in the management of pain after total knee replacement surgery. Anesth Analg 1987; 66: 401-6.

11 Scott NB, Mogensen T, Bigler D, Lund C, Kehlet $H$. Continuous thoracic extradural $0.5 \%$ bupivacaine with or without morphine: effect on quality of blockade, lung function and the surgical stress response. $\mathrm{Br} \mathrm{J}$ Anaesth 1989; 62: 253-7.

12 Logas WG, el-Baz N, el-Ganzouri A, et al. Continuous thoracic epidural analgesia for post-operative pain relief following thoracotomy: a randomized prospective study. Anesthesiology 1987; 67: 787-91.

13 Badner HN, Komar WE. Bupivacaine 0.1\% does not improve postoperative epidural fentanyl analgesia after abdominal or thoracic surgery. Can J Anaesth 1992; 39: 330-6.

14 Badner NH, Reimer EJ, Komar WE, Moote CA. Low dose bupivacaine does not improve postoperative epidural fentanyl analgesia in orthopedic patients. Anesth Analg 1991; 72: 337-41.

15 Dahl JB, Rosenberg J, Hansen BL, Hjorts $\emptyset$ NC, Kehlet $H$. Differential analgesic effects of low-dose epidural morphine and morphine-bupivacaine at rest and during mobilization after major abdominal surgery. Anesth Analg 1992; 74: 362-5.

16 Badner NH, Bhandari R, Komar WE, Ganapathy $S$. $0.125 \%$ bupivacaine - the optimum concentration for postoperative epidural fentanyl: analgesic effects. Can J Anaesth 1992; 39: A71.

17 Yeager MP, Glass DD, Neff RK, Brinik-Johnsen T. Epidural anesthesia and analgesia in high risk surgical patients. Anesthesiology 1987; 66: 729-36.

18 Tuman KJ, McCarthy RJ, March RJ, De Laria GA, Patel $R V$, Ivankovich $A D$. Effects of epidural anesthesia and analgesia on coagulation and outcome after major vascular surgery. Anesth Analg 1991; 73: 696-704.

19 Moote CA, Badner NH, Varkey GP, et al. Retrospective comparison of continuous interscalene infusion of bupivacaine vs conventional narcotic therapy for postoperative analgesia following shoulder surgery. Reg Anesth 1990; 15: $1 \mathrm{~S} ; 13$.

20 Gaumann DM, Lennon RL, Wedel DJ. Continuous axillary block for postoperative pain management. Reg Anesth 1988; 13: 77-82.

21 Thominen $M$, Pitkanen $M$, Rosenberg $P H$. Postoperative pain relief and bupivacaine plasma levels during continuous interscalene brachial plexus block. Acta Anaesthesiol Scand 1987; 31: 276-8.

22 Dahl JB, Christiansen CL, Dougard JJ, Schultz P, Carlsson $P$. Continuous blockade of the lumbar plexus after knee surgery - postoperative analgesia and bupivacaine plasma concentrations. A controlled clinical trial. Anaesthesia 1988; 43: 1015-8.

23 de Andres J, Bellver J, Burrera $L$, et al. A comparative study of analgesia after knee surgery with intraarticular bupivacaine, intraarticular morphine and lumbar plexus block. Anesth Analg 1993; 77: 727-30.

24 Schultz P, Anker-Moller E, Dahl JB, Christensen EF, Spangsberg N, Fauno P. Postoperative pain treatment after open knee surgery: continuous lumbar plexus block with bupivacaine versus epidural morphine. Reg Anesth 1991; 16: 34-7.

25 Badner NH, Dobkowski WB, Komar WE, Varkey GP. Continuous psoas lumbar plexus block versus PCA morphine for postoperative elective hip and knee joint replacement analgesia. Reg Anesth 1992; 17: 1S:86.

26 Rosenberg PH, Heino A, Scheinin B. Comparison of intramuscular analgesia, intercostal block, epidural morphine and on-demand-iv-fentanyl in the control of pain after upper abdominal surgery. Acta Anaesthesiol Scand 1984; 28: 603-7.

27 Chan VWS, Chung F, Cheng DCH, Seyone C, Chung $A$, Kirby $T J$. Analgesic and pulmonary effects of continuous intercostal nerve block following thoracotomy. Can J Anaesth 1991; 38: 733-9.

28 Richardson J, Sabanathan S, Eng J, et al. Continuous intercostal nerve block versus epidural morphine for postthoracotomy analgesia. Ann Thorac Surg 1993; 55: 377-80.

29 Frenette $L$, Boudreault $D$, Guay J. Interpleural analgesia improves pulmonary function after cholecystectomy. Can $\mathbf{J}$ Anaesth 1991; 38: 71-4.

30 Van Kleef $J W$, Burm AGC, Vletter AA. Single-dose interpleural versus intercostal blockade: nerve block characteristics and plasma concentration profiles after administration of $0.5 \%$ bupivacaine with epinephrine. Anesth Analg 1990; 70: 484-8.

31 Miguel $R$, Hubbell D. Pain management and spirometry following thoracotomy - a prospective randomized study of four techniques. J Cardiothorac Vasc Anesth 1993; 7: 529-34.

32 Tverskoy $M$, Cozacov C, Ayacke M, Bradley EL Jr, Kissin I. Postoperative pain after inguinal herniorrhaphy with different types of anesthesia. Anesth Analg 1990; 70: 29-35.

33 Sinclair $R$, Cassuto J, Hogstrom S, et al. Topical anaesthesia with lidocaine aerosol in the control of postoperative pain. Anesthesiology 1988; 68: 895-901.

34 Jebeles $J A$, Reilly JS, Gutierrez JF, Bradley EL Jr, Kissin I. The effect of pre-incisional infiltration of tonsils with bu- 
pivacaine on the pain following tonsillectomy under general anesthesia. Pain 1991; 47: 305-8.

35 Victory RA, Gajraj N, Van Elstraete A, et al. Preemptive analgesia fails to decrease pain following hysterectomy.

Anesthesiology 1993; 79: A902.

36 Smith I, Van Hemelrijck $J$, White PF, Shively $R$. Effects of local anesthesia on recovery after outpatient arthroscopy. Anesth Analg 1991; 73: 536-9.

37 Katz JA, Kaeding CS, Hill JR, Henthorn TK. The pharmacokinetics of bupivacaine when injected intra-articularly after knee arthroscopy. Anesth Analg 1988; 67: 872-5.

38 Wasudev G, Smith BE, Limbird TJ. Blood levels of bupivacaine after arthroscopy of the knee joint. Arthroscopy 1990; 6: 40-2.

39 Allen GC, St. Amand MA, Lui ACP, Johnson DH, Lindsay MP. Postarthroscopy analgesia with intraarticular bupivacaine/morphine. Anesthesiology 1993; 79: 475-80.

40 Woolf $C J$, Chong MS. Preemptive analgesia - treating postoperative pain by preventing the establishment of central sensitization. Anesth Analg 1993; 77: 362-79.

41 Pryle J, Vanner RG, Enriquez N, Reynolds $F$. Can preemptive lumbar epidural blockade reduce postoperative pain following lower abdominal surgery? Anaesthesia 1993; 48: 120-3.

42 Dahl JB, Hansen BL, Hjortso NC, Erichsen CJ, Moiniche $S$, Kehlet $H$. Influence of timing on the effect of continuous extradural analgesia with bupivacaine and morphine after major abdominal surgery. Br J Anaesth 1992; 69: 4-8.

43 Kavanagh B, Katz J, Sandler A, et al. Preoperative multimodal analgesia: a randomized, double-blind, placebo controlled study. Anesth Analg 1993; 76: S182.

44 Singelyn $F$, Vandewalle $F$, Gouverneur JM. Effect of pre vs postoperative continuous " 3 in 1 " block in postoperative pain after elective total hip replacement. Anesthesiology 1993; 79: A900.

45 Ejlersen E, Andersen HB, Eliasen K, Mogensen T. A comparison between preincisional and postincisional lidocaine infiltration and postoperative pain. Anesth Analg 1992; 74: 495-8.

46 Dierking GW, Dahl JB, Kanstrup J, Dahl A, Kehlet H. Effect of pre- vs postoperative inguinal field block on postoperative pain after herniorrhaphy. Br J Anaesth 1992; 68: 344-8.

47 Akerman B, Hellberg IB, Trossvik C. Primary evaluation of the local anesthetic properties of teh amino amide agent ropivacaine (LEA 103). Acta Anaesthesiol Scand 1988; 32 : 571-8.

48 Moller R, Covino BG. Cardiac electrophysiologic properties of bupivacaine and lidocaine compared with those of ropivacaine, a new amide local anesthetic. Anesthesiology 1990; 72: 322-9.

49 Santos AC, Arthur GR, Pedersen H, Morishima HO, Fins- ter $M$, Covino $B G$. Systemic toxicity of ropivacaine during ovine pregnancy. Anesthesiology 1991; 75: 137-41.

50 Scott DB, Lee A, Fagen D, Bowler GM, Bloomfield P, Lundh $R$. Acute toxicity of ropivacaine compared with that of bupivacaine. Anesth Analg 1989; 69: 563-9.

51. Brown DC, Carpenter RC, Thompson GE. Comparison of $0.5 \%$ ropivacaine and $0.5 \%$ bupivacaine for epidural anesthesia in patients undergoing lower extremity surgery. Anesthesiology 1990; 72: 633-6.

52 Hickey R, Hoffman J, Ramamurthy S. A comparison of ropivacaine $0.5 \%$ and bupivacaine $0.5 \%$ for brachial plexus block. Anesthesiology 1991; 74: 639-42. 


\section{Les anesthésiques locaux et le traitement de la douleur postopératoire}

Neal H. Badner MD FRCPC
Nous aborderons le rôle des anesthésiques locaux sous les rubriques suivantes:

1 Lidentification des blocs efficaces.

2 Le moment approprié pour l'injection.

3 Le choix de l'anesthésique local.

\section{Répertoire des blocs}

En commençant par l'axe cérébro-spinal, la transmission nerveuse de la douleur peut être bloquée par les anesthésiques locaux injectés aux niveaux suivants: dans l'espace sous-arachnoïdien, l'espace épidural, les plexus nerveux (bloc brachial, lombaire), les nerfs périphériques (bloc intercostal, interpleural), et les récepteurs périphériques (infiltration de plaie, injection intra-articulaire).

\section{La rachianesthésie}

Les anesthésistes injectent des anesthésiques locaux dans l'espace sous-arachnoïdien et épidural pour fin d'anesthésie chirurgicale depuis de début du siècle. Bien que la durée de l'anesthésie produite par les anesthésiques locaux de longue durée, tétracaïne ou bupivacaïne, ne se prolonge pas au-delà 3 à $4 \mathrm{~h}$, l'analgésie produite par une seule injection de lidocaïne $5 \%$ pour des manoeuvres de longue durée comme la chirurgie urologique endoscopique dure en moyenne $11 \mathrm{~h} .{ }^{1}$ Cependant pour des interventions plus lourdes, la durée de l'analgésie est beaucoup plus courte.

On peut prolonger la durée des anesthésiques locaux en utilisant des cathéters à demeure. Jusqu'à récemment, on les évitait à la période postopératoire par crainte de provoquer de la céphalée consécutive à la perforation de la dure-mère et de causer de linfection. Avec les microcathéters $26-32 \mathrm{G}$, et la diminution consécutive de lincidence des céphalées, la rachianesthésie continue a fait son apparition en analgésie postopératoire. Lors d'une étude portant sur dix patients soumis à des interventions vasculaires, de la lidocaïne $0,5-2,0 \%$ a été perfusée à $2-10$ $\mathrm{ml} \cdot \mathrm{h}^{-1}$ pour des périodes de $48 \mathrm{~h}$ ou moins. ${ }^{2}$ L'analgésie a été excellente et deux patients seulement ont eu besoin de morphine additionnelle. Pour cette étude, on avait inséré à la moitié des patients un cathéter $28 \mathrm{G}$ et à l'autre un cathéter 18G. On n'a pas mis en évidence d'instabilité hémodynamique ou de bloc moteur. Cependant, chez deux porteurs de cathéter 28G sur cinq, le pousse-seringue a mal fonctionné par occlusion du cathéter. Une étude avec suivi portant sur 19 patients identiques n'a pas rapporté d'infections. ${ }^{3}$ Lors d'une autre étude, l'addition de morphine a produit une amélioration de l'analgésie tout en permettant de diminuer la concentration de lidocaïne de $0,1-0,2 \% .{ }^{4}$ Cependant, par la suite, on a publié deux cas de syndrome de la queue de cheval dans un groupe de six patients chez lesquels un microcathéter avait été inséré pour l'analgésie peropératoire. Cette complication semble due à la distribution fautive de grandes quantités de lidocaïne hyperbare $5 \%$ dont la neurotoxicité est reconnue. Ces rapports ont forcé la $F D A$ à retirer les microcathéters de la circulation. Des cathéters modifiés qui élimineraient ces problèmes sont à l'essai. Si ces essais sont concluants, de nouvelles études seront nécessaire pour déterminer la sécurité à long terme de cette technique ou la supériorité du cathéter $18 \mathrm{G}$ qui ne présenterait pas cet inconvénient.

\section{Lépidurale}

Comme en rachianesthésie, les doses épidurales uniques ont une durée d'action limitée et par conséquent on les utilise rarement pour l'analgésie postopératoire. $\mathrm{La}$ voie caudale est courramment utilisée en chirurgie ambulatoire chez les enfants. De la bupivacaïne $0,25 \%$ à la dose de $0,5-1,0 \mathrm{ml} \cdot \mathrm{kg}^{-1}$ produit une analgésie de $4-6 \mathrm{~h}$ après une herniorraphie, orchidopexie ou cure d'hypospade. Les patients peuvent présenter des effets secondaires comme des difficultés ambulatoires et de la rétention urinaire, mais le départ de l'hôpital ne s'en trouve pas pour autant retardé. 5

Contrairement à la rachianesthésie, on introduit sans complications sérieuses des cathéters $20 \mathrm{G}$ depuis nombre années dans l'espace épidural. Ils permettent de répéter les injections et représentent la méthode la plus répandue d'analgésie postopératoire. Les anesthésiques locaux épiduraux servent à traiter la douleur postopératoire après la chirurgie abdominale, thoracique et orthopédique.

On emploie la bupivacaïne pour ses propriétés de blocage sélectif des fibres sensitives. Une fois déposée dans 
l'espace épidural, elle diffuse rapidement à travers la duremère vers la moelle où le bloc de la conduction nerveuse a vraisemblablement lieu. Le degré de blocage dépend de la concentration et du volume de l'anesthésique. Des doses intermittentes de $5-10 \mathrm{ml}$ de bupivacaïne injectées par un cathéter thoracique produisent une bonne analgésie après la thoracotomie ou la chirurgie abdominale haute; des volumes de 8-12 $\mathrm{ml}$ administrés par cathéter lombaire sont efficaces après une chirurgie abdominale basse. La durée de l'analgésie n'est cependant que de trois à quatre heures, de sorte que pour administrer l'anesthésique à plus faible concentration, il faut utiliser des perfusions continues, ex. $3-10 \mathrm{ml} \cdot \mathrm{h}^{-1}$ de bupivacaïne $0,25 \%$ ou $5-10 \mathrm{ml} \cdot \mathrm{h}^{-1}$ de bupivacaine $0,125 \%$. Ces doses procurent une bonne analgésie après une thoracotomie, une chirurgie abdominale haute ou une prothèse articulaire du genou.

L'amélioration de la fonction pulmonaire et endocrinienne n'est pas évidente. Après une chirurgie abdominale haute, l'épidurale n'a pas eu d'effets bénéfiques sur l'oxygénation et le débit expiratoire comparativement à la morphine systémique, ${ }^{6}$ mais on a rapporté une diminution de la durée de convalescence. Buckley et al. ont noté une diminution de l'incidence des complications respiratoires chez les obèses morbides soumis à une chirurgie abdominale. ${ }^{7}$ Les effets sur la réponse métabolique au stress chirurgical, c.-à-d. la capacité d'inhiber l'élévation de la cortisolémie, de linsulinémie et du glucagon, semblent dépendre du site de la chirurgie. En chirurgie abdominale basse, on ne retrouve pas cette poussée hormonale, alors qu'en chirurgie abdominale haute, on la retrouve même chez des patients qui ont profité d'un bloc thoracique haut après l'intervention. ${ }^{8,9}$

Les anesthésiques locaux ont des effets secondaires et c'est leur problème majeur. Ces effets sont liés à leur mécanisme d'action: le bloc sympathique provoque de l'hypotension, le bloc moteur de la faiblesse musculaire. Après thoracotomie ou chirurgie abdominale haute, une étude rapporte de l'hypotension nécessitant traitement chez la majorité des malades ${ }^{6}$ et après une prothèse articulaire du genou la moitié des patients d'une autre étude ont développé un bloc moteur d'une durée de 48 heures. ${ }^{10}$ En plus d'être incommodants, ces effets secondaires retardent l'ambulation, un des objectifs d'une bonne analgésie postopératoire. Pour ces raisons et malgré leur efficacité, les anesthésiques locaux épiduraux n'ont jamais été utilisés universellement pour l'analgésie postopératoire.

Récemment, dans le but de diminuer la posologie des morphiniques épiduraux, on a perfusé des mélanges de morphiniques et d'anesthésiques locaux. Comme ces deux drogues ont des mécanismes d'action différents, on pourrait présumer une synergie de leurs effets, ce qui permettrait de diminuer la dose de chacune: ainsi on réduirait l'incidence des effets secondaires des anesthésiques locaux et ceux de la morphine épidurale dont la nausée et les vomissements, le prurit, la rétension urinaire et la dépression respiratoire. L'association de morphine à la bupivacaïne $0,5 \%$ en perfusion soulage complètement la douleur consécutive à une intervention abdominale haute. " Toutefois, tous les patients développent un bloc sensitif thoracique haut et on doit traiter l'hypotension chez $\mathbf{2 0 \%}$ de ceux-ci. A l'inverse, l'association en épidurale de bupivacaine $0,1 \%$ et de morphine ou de fentanyl n'améliore pas l'analgésie après une thoracotomie, après une chirurgie abdominale haute $e^{12,13}$ ou après une prothèse articulaire du genou. ${ }^{14} \mathrm{La}$ concentration de bupivacaïne, pour être efficace, doit se situer entre 0,1 et $0,5 \%$. Ceci a été confirmé par plusieurs études au cours desquelles l'ajout de bupivacaïne aux concentrations de $0,125 \%$ et de $2,5 \%$ à été trouvé supérieur à la morphine et au fentanyl seuls en épidural, la concentration inférieure de bupivacaïne présentant moins d'effets secondaires. ${ }^{15,16} \mathrm{Ce}$ qui est plus important, lorsqu'on la compare aux morphiniques systémiques, on a démontré que l'association épidurale de morphiniques et d'anesthésiques locaux diminue la morbidité et la mortalité chez les patients à hauts risques, possiblement grâce à ses effets sur les mécanismes de coagulation. ${ }^{17,18}$

\section{Blocs plexiques}

\section{BRACHIAL}

Les injections plexiques uniques, comme les injections sous-arachnoïdiennes et épidurales, produisent une analgésie de durée limitée. Toutefois, on peut aussi introduire un cathéter près du plexus brachial par approche axillaire et interscalénique. Des perfusions de $3-10 \mathrm{ml} \cdot \mathrm{h}^{-1}$ de bupivacaïne $0,125-25 \%$ procurent une bonne analgésie et permettent de réduire les doses de morphiniques pour une variété d'interventions au membre supérieur. ${ }^{10,20}$ Lors d'une étude clinique, on a noté que la concentration de bupivacaïne $0,25 \%$ provoquait des symptômes de toxicité chez 3 des 20 patients, et on a récommandé la concentration de $0,125 \%$. ${ }^{21}$ L'insertion d'un cathéter est techniquement plus difficile et il se déplace aisément avec les mouvements. Les complications sérieuses proviennent de la toxicité systémique. Ce risque augmente avec la concentration et la durée de la perfusion.

\section{LOMBAIRE}

Comme avec le plexus brachial, on peut produire l'analgésie après une chirurgie du membre inférieur par des injections du plexus lombaire, soit dans le compartiment du psoas, soit par l'approche fémorale " 3 dans 1 ». Avec 20 à $30 \mathrm{ml}$ de bupivacaïne $0,5 \%$, on diminue le besoin 
de morphinique pendant $24 \mathrm{~h}$ après la chirurgie du ligament croisé antérieur. Les deux approches ont été utilisées pour l'insertion de cathéters après des interventions sur le genou et la hanche. Après une chirurgie du genou, des perfusions de $5-10 \mathrm{ml} \cdot \mathrm{h}^{-1}$ de bupivacaïne $0,25 \%$ par un cathéter introduit dans la gaine fémorale ont été supérieures autant au placébo ${ }^{22}$ qu'aux injections intraarticulaires de morphine ou de bupivacaïne (voir plus bas), ${ }^{23}$ avec un degré d'analgésie égal et une incidence inférieure d'effets secondaires (nausées, vomissements, prurit, rétention urinaire) que la morphine épidurale. ${ }^{24}$ Ces doses de bupivacaïne peuvent produire des niveaux systémiques élevés et c'est la raison pour laquelle la concentration de bupivacaïne $0,125 \%$ est recommandée. Des perfusions équivalentes de bupivacaïne dans la compartiment du psoas permettre de réduire le besoin en morphinique après une chirurgie de la hanche. ${ }^{25}$ Comme pour le bloc continu du plexus brachial, ces manoeuvres sont techniquement plus difficiles que l'insertion épidurale ou sous-arachnoïdienne d'un cathéter.

\section{Nerfs périphériques}

\section{BLOCS INTERCOSTAUX}

On réalise ces blocs en injectant un anesthésique local, ordinairement de la bupivacaïne à $0,5 \%$ en glissant la pointe de l'aiguille sur le rebord inférieur de la côte, à $7-8 \mathrm{~cm}$ de la ligne médiane postérieure. Le bloc intercostal produit l'analgésie et améliore la fonction pulmonaire après une intervention thoracique (lorsqu'on infiltre les deux côtes sus-jacentes et les deux côtes sous-jacentes à l'incision) ou pour une chirurgue abdominale haute (de la $7 \mathrm{e}$ à la 11e côte) avec la même efficacité que la morphine épidurale. ${ }^{26} \mathrm{La}$ duré d'action est de l'ordre de quatre à six heures, après lesquelles ils faut répéter cinq injections, ce qui est pénible et douloureux. Ceci peut être évité si le chirurgien insère deux cathéters intrapleuraux dans l'espace intercostal par la plaie chirurgicale au cours de lintervention thoracique. A la période postopératoire, l'injection par le cathéter de bupivacaïne $0,5 \%$ adrénalinée à 1:200 000 produit une analgésie de bonne qualité, diminue le besoin de morphinique, et améliore la fonction respiratoire (VEMS, CVF, DEP) comparativement au placébo, ${ }^{27}$ mais cette technique nécessite que le chirurgien sy intéresse et accepte de collaborer.

\section{BLOCS INTERPLEURAUX}

Cette technique a été révélée au milieu des années 1980 . Elle requiert linsertion dans le huitième ou neuvième espace intercostal à environ $10 \mathrm{~cm}$ de la ligne médiane d'une aiguille Tuohy attachée à une seringue remplie d'air. L'espace interpleural est identifié au moment où la pression négative aspire le piston de la seringue. Par le suite, un cathéter est introduit à travers l'aiguille. On présume que l'analgésie est produite par diffusion de l'anesthésique dans l'espace paravertébral où il se disperse et bloque plusieurs nerfs intercostaux. Après une cholécystectomie ouverte, linjection de $20 \mathrm{ml}$ de bupivacaine $0,5 \%$ adrénalinée à 1:200 000 produit une bonne analgésie qui dure en moyenne six heures et améliore le VEMS et la CVF comparativement aux morphiniques systémiques. ${ }^{29}$ Ces facteurs associés à la facilité relative de la technique l'ont rendu rapidement populaire malgré un risque accru de pneumothorax, sa durée d'action plutôt courte et une absorption importante de bupivacaïne. ${ }^{30}$ Après une thoracotomie, des études randomisées n'ont montré pour cette technique aucun avantage sur le placébo et une infériorité nette comparativement à la morphine épidurale. ${ }^{31}$ La substitution de la laparascopie à cholécystectomie ouverte fera vraisemblement diminuer dans l'avenir son utilisation.

\section{Récepteurs périphériques}

\section{LTNFILTRATION DE LA PLAIE}

La simple injection d'un anesthésique local dans une plaie peut procurer une analgésie qui dépasse la durée d'action de l'anesthésique lui-même. Le patient qui reçoit une injection de $40 \mathrm{ml}$ de bupivacaïne $0,25 \%$ dans sa plaie d'herniorraphie est mieux soulagé pendant $48 \mathrm{~h}$ que celui qui n'en reçoit pas. ${ }^{32}$ Même sans injection, la vaporisation de $200 \mathrm{mg}$ de lidocaine en aérosol sur une plaie d'herniorraphie diminue les besoins en morphinique et améliore l'analgésie pour $24 \mathrm{~h}$ comparativement au placébo; cette étude ne rapporte pas d'infection de plaie et l'absorption systémique a été minime. ${ }^{33}$ Linfiltration des fosses amygdaliennes après amygdalectomie avec 3-5 $\mathrm{ml}$ de bupivacaïne $0,25 \%$ adrénalinée à $1: 200000$ améliore l'analgésie pendant cinq jours. ${ }^{34} \mathrm{Ce}$ mode dinfiltration n'est toutefois pas efficace après une chirurgie plus lourde, portant sur un viscère, comme l'hystérectomie abdominale. ${ }^{35}$

\section{LINJECTION INTRA-ARTICULAIRE}

Une technique relativement simple qui consiste à injecter un anesthésique local comme la bupivacaïne dans une articulation après une chirurgie arthroscopique peut diminuer les besoins en morphinique et faciliter l'ambulation plus précocément qu'un placébo. ${ }^{36}$ On utilise des volume de $30 \mathrm{ml}$ de bupivacaïne $0,25-0,5 \%$ avant le dégonflage du garot. Ces quantités sont basées sur la constatation qu'un volume de $40 \mathrm{ml}$ de bupivacaïne $0,25 \%(100 \mathrm{mg})$ est très peu absorbe, ${ }^{37}$ alors que l'injection de $30 \mathrm{ml}$ de bupivacaïne $0,75 \%$ (225 mg) élève les taux sanguins au niveau toxique chez quatre patients parmi les quinze étudiés. ${ }^{38}$ La découverte récente de récepteurs morphi- 
niques articulaires a conduit à linjection intra-articulaire de morphine (1-5 mg) en association à la bupivacaïne. Cette combinaison produirait une analgésie supérieure à l'analgésie produite par les deux drogues utilisées séparément. ${ }^{39}$ La majorité des études à date se sont intéressées à la chirurgie du genou bien que l'utilisation de la morphine et de la bupivacaïne intra-articulaire se soit aussi avérée efficace pour la manipulation d'épaules bloquées.

\section{Synchronisation}

Par intuition, on serait porté à croire que le meilleur moment pour injecter serait à la fin de l'intervention, ce qui prolongerait la durée de l'analgésie. Cependant, des études chez l'animal ont montré que le blocage préincisionnel pourrait être supérieur. Ceci est basé sur la théorie qui énonce qu'après un stimulus nociceptif, l'activation des neurones sensitifs de la corne dorsale provoque une activation plus importante des interneurones de la corne dorsale que le stimulus initial. Ces interneurones en plus de faire des synapses avec les neurones ascendants, font des synapses avec les neurones efférents des tissus lésés, qui retournent à la corne dorsale. Cette boucle fonctionne en rétroaction avec elle-même et crée un phénomène d'amplification qui fait que la réponse excède le stimulus initial. ${ }^{40}$ En bloquant la transmission afférente initiale (" pre-emptive block ") préalablement à la lésion, on peut prévenir ce phénomène d'amplification. Le résultat serait alors supérieur à celui du bloc réalisé après le déclenchement du phénomène d'amplification.

On a essayé de vérifier le phénomène chez l'humain mais sans résultats probants. L'anesthésie rachidienne, qui est une forme d'analgésie pré-emptive, diminue la perception douloureuse jusqu'à $48 \mathrm{~h}$ après une herniorraphie inguinale. ${ }^{32}$ Cependant, après une hystérectomie abdominale ou une chirurgie colique, les patients sous anesthésie générale qui ont reçu un bloc pré-incisionnel n'ont pas demandé moins de morphinique et n'ont pas eu une analgésie supérieure à celle que procurait une injection post-incisionnelle identique ou une supplémentation par épidurale. ${ }^{43}$ Finalement, le bloc plexique lombaire par la technique fémorale " 3 dans 1 " n'a pas été trouvé plus efficace quand il a été administré avant le remplacement total de la hanche qu'après, quoique dans les deux cas, on ait pu diminuer les injections de morphiniques en comparaison avec ceux qui n'avaient pas subi de bloc. ${ }^{44}$ Comme linfiltration avant l'incision de la plaie de hernie inguinale procure une meilleure analgésie que linfiltration après l'incision, on conclut que la première technique produit de l'analgésie pré-emptive pour la cure de hernie inguinale. ${ }^{45}$ Toutefois, une étude similaire comparant les deux techniques n'a pas montré de différence d'intensité douloureuse postopératoire. ${ }^{46} \mathrm{Il}$ apparaît donc évident que des études supplémentaires sont requises pour déterminer si certains blocs seraient profitables avant linncision.

\section{Les anesthésiques locaux}

Comme on vient de le voir, l'anesthésique local le plus utilisé est la bupivacaïne. A part certains effets secondaires liés au type de bloc, la toxicité systémique constitue la plus sérieuse des complications. Pour l'anesthésique local, ceci signifie cardiotoxicité et neurotoxicité sous forme d'excitabilité et de dépression. La neurotoxicité se manifeste par des convulsions et des pertes de conscience, alors que la cardiotoxicité se manifeste par l'arythmie et l'arrêt cardiaque. On sait que la bupivacaïne est plus cardiotoxique que les autres anesthésiques locaux comme la lidocaïne et que cette toxicité s'accroit pendant la grossesse.

Cette toxicité a conduit au développement de la ropivacainne, un analogue de la bupivacaïne qui possède une chaine latérale propyl au lieu d'une chaine latérale butyl comme la bupivacaïne. Les deux produits ont des propriétés physiques identiques mais la ropivacaïne est moins liposoluble. L'autre différence consiste en ce que la bupivacaïne est une mélange racémique alors que la ropivacaïne est produite sous la forme énantiomérique $\mathrm{S}(-)$. L'énantiomère $\mathrm{S}(-)$ est moins cardiotoxique et possède une durée d'action plus longue que le $R(+)$ ou que le mélange racémique chez l'animal. ${ }^{47}$ On a démontré que chez l'animal la toxicité de la ropivacaïne est de beaucoup inférieure à celle de la bupivacaine, ${ }^{48}$ et qu'elle ne varie pas pendant la grossesse. ${ }^{49} \mathrm{Chez}$ des volontaires, aux mêmes doses, la ropivacaïne $i v$ produit moins de symptômes neurologiques, alors que des doses plus fortes et des concentrations plasmatiques plus élevées sont requises pour produire une dépression équivalente de la conductivité et de la contractilité. ${ }^{50}$ En clinique, la ropivacaïne $0,5 \%$ utilisée pour l'épidurale et le bloc du plexus brachial produit un bloc moteur et sensitif identique au regard de la période de latence et d'une intensité égale à celui de la bupivacaïne $0,5 \%{ }^{51,52}$ mais la durée d'action de la ropivacaïne est légèrement plus courte. La perfusion continue de ropivacaïne fait présentement l'objet d'études dont les résultats sont attendus.

\section{Références \\ (Voir page R45)}

